\title{
RESIKO MORAL HAZARD \\ PADA PERBANKAN SYARIAH DI INDONESIA
}

\author{
Rina Mandara Harahap \\ Fakultas Syariah dan Ekonomi Islam IAIN Pontianak \\ Email: rina.mandara91@gmail.com
}

\begin{abstract}
Abstrack
The problems of Principal-Agent often occurred in financing scheme of Islamic banking as the effect of imbalance information between Shahibul Maal and Mudharib are adverse selection and moral hazard. Providing adequate information and determining optimum sharing schemethat meet the utility of Islamic banking and client can reduce the problem of adverse selection and moral hazard. Even though financial product is highly risked, yet it can be reduced by optimizing sharing scheme and thus the financial amount can be increased.

Furthermore, the effective supervision of the corporation as a control management is necessary to minimize financial risk. Then, Good Corporate and Good Governance (GCG) Principles must be implemented in Islamic banking as a consequence of public responsibility in running the bank according to shariah principle based on Al-Qur'an, Hadith, and Ijmā
\end{abstract}

Keyword: Moral Hazard, Principal Agent, Profit-Sharing Scheme, and Good Cooporate Governance.

\begin{abstract}
Abstrak
Permasalahan Principal-Agent merupakan permasalahan yang sering terjadi dalam pembiayaan pada perbankan syariah. Permasalahan tersebut terjadi akibat adanya ketidakseimbangan informasi antara șāhibul māl dan mudārib. Masalah PrincipalAgent yang timbul tersebut dibagi menjadi dua yaitu adverse selection dan moral hazard.

Penetapan skema bagi hasil yang optimal diharapkan dapat menekan kedua permasalahan yang timbul dalam pembiayaan pada perbankan syariah. Dengan memanfaatkan informasi untuk kepentingan bersama maka masalah adverse selection dan moral hazard yang terjadi dapat ditekan seminimal mungkin. Meskipun produk pembiayaan memiliki resiko yang tinggi, dengan mengoptimalkan skema bagi hasil pada pembiayaan tersebut maka resiko-resiko yang ada dapat ditekan dan nantinya dapat meningkatnya jumlah pembiayaan pada bank syariah.

Selain itu penerapan mekanisme pengawasan korporasi yang efektif perlu dilakukan sebagai mekanisme pengendalian untuk mengatur dan mengelola perusahaan agar mengurangi resiko pembiayaan. Penerapan prinsip-prinsip Good Corporate Governance (GCG) menjadi suatu keharusan bagi institusi bank syariah. Hal ini disebabkan oleh adanya tanggung jawab publik berkaitan dengan kegiatan operasional bank yang harus mematuhi ketentuan-ketentuan yang telah digariskan dalam hukum dan juga berkaitan dengan kepatuhan bank syariah terhadap prinsip-prinsip syariah sebagaimana yang telah digariskan dalam al-Qur'an, Hadis, dan Ijmak para ulama.
\end{abstract}


Kata kunci: Moral Hazard, Principal-Agent, skema bagi hasil, Good Corporate Governance.

\section{Pendahuluan}

Bank sebagai lembaga intermediasi di bidang keuangan, berfungsi untuk menghimpun dana dari masyarakat dan menyalurkannya kembali ke masyarakat. Selain itu, bank juga mempunyai peranan yang sangat penting dalam menopang stabilitas perekonomian negara dan meningkatkan kesejahteraan masyarakat. Adanya kepercayaan rnasyarakat terhadap lembaga perbankan menyebabkan masyarakat mau menempatkan dananya di lernbaga perbankan, di sisi lain, adanya faktor kepercayaan menyebabkan lembaga perbankan mau meminjamkan dananya kepada masyarakat. Berkaitan dengan faktor kepercayaan tersebut, maka Bank Indonesia selaku bank sentral telah mengeluarkan berbagai kebijakan perbankan yang diarahkan pada upaya untuk mempercepat proses restrukturisasi perbankan dan meningkatkan ketahanan sistem perbankan.

Ditinjau dari prinsipnya di Indonesia terdapat dua jenis bank ditinjau dari prinsipnya yaitu bank konvensional dan bank syariah. Bank konvensional adalah bank yang menghimpun dana dari masyarakat serta menyalurkannya kepada pihak-pihak yang kekurangan dana dalam rangka meningkatkan taraf hidup rakyat banyak. Bank syariah merupakan bank yang menghimpun dana dari masyarakat dan menyalurkannya kepada pihak-pihak yang kekurangan dana dalam rangka mensejahterahkan rakyat dan berdasarkan prinsip-prinsip syariat Islam.

Bank syariah di Indonesia dalam rentang waktu yang relatif singkat telah memperlihatkan kemajuan yang cukup berarti dan semakin memperlihatkan eksistensinya dalam sistem perekonomian nasional. Indonesia yang merupakan negara dengan jumlah penduduk muslim terbesar di dunia menjadikan perkembangan perbankan syariah memiliki peluang besar. Perkembangan ini dapat kita lihat dengan semakin banyaknya perbankan syariah yang ada di Indonesia. Masyarakat Indonesia semakin banyak yang memilih untuk menabung dan menggunakan jasa perbankan syariah.

Bank syariah yang berfungsi sebagai lembaga intermediasi keuangan, melaksanakan kegiatan operasionalnya dengan menghimpun dana dari masyarakat dan kemudian menyalurkannya kembali kepada masyarakat melalui pembiayaan. Dana yang 
dihimpun dari masyarakat biasanya disimpan dalam bentuk giro, tabungan dan deposito baik dengan prinsip wadi'ah maupun prinsip mudārabah. Sedangkan penyaluran dana dilakukan oleh bank syariah melalui pembiayaan dengan empat pola penyaluran yaitu prinsip jual beli, prinsip bagi hasil, prinsip ujroh dan akad pelengkap.

Seperti halnya perusahaan, tujuan akhir dari bank adalah menjaga kelangsungan hidup bank melalui usaha untuk meraih keuntungan. Artinya, pendapatan harus lebih besar dari semua biaya yang dikeluarkan, terutama mengingat bank bekerja dengan dana yang diperoleh dari masyarakat yang dititipkan pada bank atas dasar kepercayaan. Oleh karena itu, kegiatan operasional harus dilaksanakan seefektif dan seefisien mungkin untuk mendapatkan keuntungan bagi perusahaan. Karena dengan melihat keuntungan yang diperoleh dapat dinilai kesehatan suatu bank dan menentukan keberhasilan suatu bank.

Untuk meningkatkan keuntungannya bank harus melakukan upaya pemaksimalan perolehan laba, salah satunya dengan pemanfaatan aktiva produktif. Aktiva produktif akan menghasilkan laba jika perusahaan menyalurkannya kepada masyarakat dalam bentuk berbagai macam produk usaha. Penyalurannya pun harus proposional, karena pengelolahan aktiva produktif akan berpengaruh terhadap perolehan laba, semakin besar pemanfaatan aktiva produktif seharusnya mampu menghasilkan laba yang besar pula, dan laba yang besar akan berdampak pada keuntungan bank.

Seperti industri lainnya yang berorientasi laba (profit oriented), perbankan juga menjalankan peran pengawasan (monitoring) terhadap debitur, di sisi lain industri ini juga di-monitor oleh deposan, termasuk oleh regulator dan lembaga penjamin simpanan. Deposan tidak memonitor secara langsung penggunaan dana yang ditempatkan ke debitur, namun lembaga perbankan yang memonitor debitur sebagai amanat deposan atau penyimpan dana di bank. Monitoring atau kontrol ini akan berjalan sebagaimana mestinya ketika mereka memiliki kepentingan yang selaras. Bila tidak terjadi keselarasan insentif dan kepentingan diantara mereka, maka akan terjadi konflik kepentingan yang berdampak akan menyulitkan fungsi monitoring, bahkan pemegang saham dapat melakukan pengambilan risiko tinggi atas beban pemegang saham lain, deposan dan atau lembaga penjamin simpanan. Oleh karena itu peran regulasi berfungsi sebagai representasi publik terkait dengan monitoring pada industri perbankan. 
Pada industri ini, kesulitan utama dalam pengawasan (monitoring) adalah karena adanya asimetri informasi (asymmetry information) atau ketidak selarasan informasi, yang menjadikan industri ini rawan masalah moral hazard. Kepentingan pemegang saham dapat mengorbankan pihak lain (misal deposan, lembaga penjamin atau pemegang saham minoritas) untuk keuntungan dirinya, kepentingan manajemen bisa mengorbankan kepentingan pemegang saham, kepentingan debitur dapat mengorbankan kepentingan bank. Pada Industri perbankan ini, para agen atau bankir sering mempunyai informasi yang lebih baik mengenai bisnis tersebut daripada pihak principal (pendiri), para agen bisa memaksimumkan utilitasnya atas beban pihak lain, atau paling sedikit agen tidak menanggung secara penuh atau sepadan dengan kerugian bila terjadi. Para pemegang saham dan manajemen bisa mempunyai agenda tersembunyi yang bertentangan dengan etika dan prinsip-prinsip pengelolaan perbankan yang sehat karena kegagalan bank akan menjadi beban penjamin simpanan atau deposan. Sangat wajar kalau industri perbankan di Indonesia ini senantiasa diarahkan agar menjadi bank yang sehat serta dijaga stabilitas dan performancenya dari berbagai goncangan dan dampak buruk karena perilaku buruk para bankir, pemilik maupun para deposannya. Hal ini merupakan konsekuensi menjaga industri perbankan nasional yang pada hakekatnya akan mendukung perkembangan ekonomi Indonesia selaku intermediator penyaluran berbagai skim pendanaan. Efektifitas perbankan yang sehat akan mempengaruhi dan mendukung berbagai kebijakan fiskal yang diluncurkan pemerintah. Tentu saja dengan timbulnya moral hazard mempunyai implikasi kebocoran dan mengakibatkan biaya fiskal yang mahal.

Perbankan syariah merupakan suatu sistem perbankan yang dikembangkan berdasarkan syariah (hukum Islam). Usaha pembentukan sistem ini didasari oleh larangan dalam ajaran agama Islam untuk memungut maupun meminjam dengan bunga atau yang disebut dengan riba serta larangan investasi untuk usaha-usaha yang dikategorikan haram (misal: usaha yang berkaitan dengan produksi makanan/minuman haram, usaha media yang tidak Islami dll), dimana hal ini tidak dapat dijamin oleh sistem perbankan konvensional.

Bank Syariah adalah lembaga keuangan yang tata cara beroperasinya dalam penghimpunan dana maupun dalam rangka penyaluran dana, memberikan dan mengenakan imbalan didasarkan pada tata cara bermuamalat secara Islami atau prinsip 
syariah, yakni mengacu pada ketentuan-ketentuan Al-Qur'an dan hadis atau dengan kata lain, Bank Syariah adalah lembaga keuangan yang usaha pokoknya memberikan pembiayaan dan jasa-jasa lainnya dalam lalu lintas pembayaran serta peredaran uang yang pengoperasian disesuaikan dengan prinsip syariat Islam. ${ }^{1}$

Berkembangnya bank syariah saat ini merupakan bukti bahwa ajaran agama Islam juga bisa diterapkan dalam kegiatan perekonomian. Hal ini didukung dengan keunggulan sistem bank syariah yang menggunakan skema bagi hasil. Skema bagi hasil atau yang biasa dalam fiqh mu'āmalah disebut sebagai transaksi mudārabah merupakan perbedaan antara bank konvensional dan bank syariah. Bank syariah mempunyai core product pembiayaan berupa produk bagi hasil yang dikembangkan dalam produk mushārakah dan mudāarabah.

Prinsip bagi hasil (profit sharing) merupakan karakteristik umum dan landasan dasar bagi operasional bank Islam secara keseluruhan. Secara syariah, prinsipnya berdasarkan kaidah al-mud̦ārabah. Berdasarkan prinsip ini, bank Islam berfungsi sebagai mitra, baik dengan penabung maupun dengan pengusaha yang meminjam dana. Kontrak mudāarabah merupakan salah satu bentuk mekanisme keuangan syariah yang digunakan untuk menggantikan sistem bunga. Dalam kontrak ini terdapat hubungan antara pemilik modal (șāhibul māl/principal) dengan pelaku usaha (muḍārib/agent). Kontrak mudāarabah adalah kontrak kerjasama yang menanggung untung dan rugi antara pemilik dana (bank/principal) dengan nasabah (kreditur/agent). ${ }^{2}$

Hubungan kontrak keuangan seperti dalam mudāarabah ini biasanya dikenal dengan nama hubungan keagenan. Oleh karena itu, kontrak seperti ini menuntut adanya transparansi bagi kedua belah pihak. Jika salah satu pihak (utamanya nasabah) tidak menyampaikan secara transparan tentang hal-hal yang berhubungan dengan perolehan hasil, sehingga dapat terjadi aktivitas adverse selection yaitu masalah yang timbul dalam menyeleksi nasabah yang akan diberikan pembiayaan, hal ini disebabkan karena susahnya pihak bank untuk mengetahui dengan pasti kriteria yang dimiliki calon nasabah, bank mungkin akan salah dalam menilai kriteria nasabah. Sedangkan moral hazard yaitu masalah yang dihadapi pihak bank ketika pembiayaan sudah dijalankan,

1 Mufraini, Arief, Modul Perbankan Syariah Landasan Teori dan Praktek (Jakarta: Fakultas Ekonomi dan IImu Sosial UIN Jakarta, 2008), 17.

2 Antonio, Muhammad Syafi, Bank Syariah: Dari Teori ke Praktik (Jakarta: Gema Insani, 2001), 
adanya risiko bahwa nasabah kemungkinan menggunakan dana yang diberikan tidak untuk semestinya dan kemungkinan nasabah akan melaporkan hasil yang didapatkan tidak sesuai dengan yang seharusnya. Dalam transaksi keuangan, masalah adverse selection dan moral hazard merupakan masalah asymmetric information. Kontrak mudāarabah adalah kontrak keuangan yang sarat dengan aktivitas asymmetric information.

Mustafa Edwin N. dan Ranti Wiliasih mengemukakan bahwa sikap ketidakhatihatian dalam menyalurkan dana pihak ketiga juga dapat dikategorikan sebagai tindakan moral hazard secara tidak langsung. Berdasarkan definisi moral hazard tersebut kita dapat melihat kondisi kolapsnya beberapa bank di Indonesia pada saat krisis ekonomi terjadi dari sisi moral hazard. Kurangnya sikap kehati-hatian dari pihak menajemen bank dalam menyalurkan DPK menimbulkan moral hazard secara tidak langsung kepada nasabah, sehingga meningkatkan rasio kredit macet. Selain itu pendistribusian risiko yang tidak merata juga bisa menjadi faktor terjadinya kasus pembiayaan bermasalah. Risiko yang yang harus diterima oleh pemilik dana lebih besar dari pada risiko yang diterima oleh pihak bank. ${ }^{3}$

Walaupun pembiayaan mudāarabah memiliki risiko yang lebih tinggi diantara akad pembiayaan yang lain, tetapi pembiayaan mudārabah ini pada kenyataannya tetap berjalan. Sehingga peneliti menduga terdapat prosedur atau manajemen risiko yang telah diterapkan oleh Bank Syariah untuk mengurangi resiko yang ada. Adanya sistem kerja perusahaan, sistem dan standar operasional perusahaan yang berbeda untuk setiap bank membuat kajian ini menarik untuk diteliti karena masing-masing bank memiliki pengelolaan risiko yang berbeda pula.

\section{Pembahasan}

Menurut PSAK 105 pembiayaan muḍārabah merupakan akad kerjasama usaha antara dua pihak, dimana pihak pertama (pemilik dana) menyediakan seluruh dana, sedangkan pihak kedua (pengelola dana) bertindak selaku pengelola, dan keuntungan usaha dibagi di antara mereka sesuai kesepakatan sedangkan kerugian finansial hanya ditanggung oleh pengelola dana. Adanya risiko pembiayaan mudāarabah akan

3 Mustafa Edwin Nasution dan Ranti Wiliasih, "Profit Sharing dan Moral Hazard dalam Penyaluran Dana Pihak Ketiga Bank Umum Syariah di Indonesia," Jurnal Ekonomi Pembangunan Indonesia, Vol.VIII No.02, Januari 2007, 106. 
menyebabkan kerugian pada bank karena bank menanggung sepenuhnya atas kerugian tersebut. Sedangkan pembiayaan Mushārakah menurut PSAK No.106 merupakan akad kerjasama antara dua pihak atau lebih untuk suatu usaha tertentu, dimana masingmasing pihak memberikan konstribusi dana dengan ketentuan bahwa keuntungan dibagi berdasarkan kesepakatan sedangkan kerugian dibagi berdasarkan porsi kontribusi dana.

Kerugian yang cukup besar yang diakibatkan oleh pemberian pembiayaan yang tidak lancar akan berpengaruh terhadap tingkat profitabilitas bank. Tingkat profitabilitas yang rendah mengindikasikan bahwa kemampuan manajemen menghasilkan laba belum maksimal. Dengan risiko ketidakpastian dari pembiayaan yang telah disalurkan maka bank syariah dituntut untuk memiliki manajemen syariah yang handal untuk meminimalisir risiko pembiayaan, dengan adanya manajemen yang handal risiko yang dapat dideteksi dan dilakukan pencarian solusi untuk mengatasinya sehingga kelangsungan hidup perusahaan tidak terganggu dan kepercayaan masyarakat tidak berkurang.

Untuk mengendalikan risiko seminimal mungkin menjadi penting, karena besar kecilnya risiko pembiayaan akan berdampak pada perolehan keuntungan. Besar kecilnya keuntungan dan kemampuan bank menghasilkan laba akan menggambarkan besar kecilnya profitabilitas yang diperoleh bank. Maka dapat diketahui bahwa risiko pembiayaan dapat mempengaruhi besar kecilnya profitabilitas. Jika profitabilitas rendah mengindikasikan manajemen tidak memanfaatkan aktiva produktif yang dimiliki perusahaan secara maksimal. Akibatnya tingkat kepercayaan masyarakat akan menurun.

Akad mudāarabah dikenal sebagai akad atau perjanjian atas sekian uang untuk dijalankan atau diputar oleh amil (pengusaha) dalam perdagangan, kemudian keuntungannya dibagikan diantara keduanya berdasarkan syarat-syarat yang sudah ditentukan. Menurut PSAK 105 keuntungan usaha dalam akad mudārabah dibagi dua di antara mereka sesuai kesepakatan sedangkan kerugian finansial hanya ditanggung oleh pemilik dana. Akad mudārabah merupakan akad yang memiliki risiko paling tinggi, karena akad ini merupakan akad yang memerlukan kepercayaan kedua belah pihak

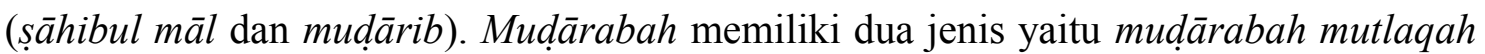
dan mudārabah muqayyadah. Mudārabah mutlaqah adalah bentuk kerja sama antara 
șāhibul māl dan mudạrib yang memiliki ruang lingkup sangat luas dan tidak dibatasi oleh spesifikasi jenis usaha, waktu, dan daerah bisnis. ${ }^{4}$

Moral hazard dapat didefinisikan menjadi empat berdasarkan kondisi yang berbeda. Pertama, moral hazard terjadi karena kondisi monitoring disability (hidden action). Prinsipal tidak dapat mengamati atau memonitor perilaku agen. Ketidakmampuan memonitor tindakan secara konseptual menunjukkan ketidakpastian mengenai hubungan antara tindakan agen dengan hasil untuk principal, ketidaksamaan informasi antara kedua pihak, kebutuhan untuk melakukan kesepakatan mengenai masalah insentif untuk agen, ketidakmampuan membuat kontrak untuk menghilangkan masalah (tanpa kemampuan untuk memonitor perilaku agen, kontrak yang dibuat tidak dapat dilaksanakan). Prinsipal dan agen diasumsikan mempunyai potensi untuk konflik kepentingan. Kedua, moral hazard terjadi karena adanya undesirable behavior production (perilaku yang tidak diinginkan) dipandang dari perspektif prinsipal. Agen tidak cukup menjamin tindakannya akan menguntungkan prinsipal atau bisa mengurangi kerugian yang mungkin terjadi. Moral hazard diidentifikasi sebagai hasil dari perilaku agen yang berisiko. Ketiga, moral hazard terjadi karena undesirable outcome (impact) production. Moral hazard merupakan bentuk oportunisme pasca kontraktual yang timbul karena tindakan yang mempunyai konsekuensi efisiensi yang tidak dapat diobservasi secara bebas sehingga seseorang bisa memenuhi kepentingan pribadinya atas biaya pihak lain. Keempat, moral hazard sebagai bentuk dari morals disability. Moral hazard terjadi karena kecenderungan perilaku-perilaku yang tidak bermoral seperti ketidakjujuran, ketidakpedulian, ketidaktahuan atau ketidaktabahan hati. $^{5}$

Masalah moral hazard atau perilaku oportunistik yang dilakukan oleh agen muncul ketika prinsipal tidak dapat mengetahui tindakan agen karena ada biaya untuk mengawasi tindakan agen dan tidak dapat menyimpulkan tindakan agen dengan melihat hasilnya karena tidak secara lengkap dapat direpresentasikan. Lalu prinsipal menghadapi dua kesulitan. Pertama, tidak dapat mendesain kontrak berdasarkan observasinya pada indakan agen karena secara umum biaya pengawasan menjadi

4 Antonio, Muhammad Syafii, Bank Syariah: Dari Teori ke Praktik (Jakarta: Gema Insani, 2001), 97.

5 Mitnick, Barry, (t.p: The Hazard of Agency, Working Paper, 1996), 7-10. 
hambatan. Kedua, prinsipal tidak dapat mendasarkan kontrak pada hasil karena ketidakpastian antara tindakan agen dan hasil serta agen merupakan pihak yang netral terhadap risiko. Prinsipal tidak dapat secara kontraktual memberi tugas kepada agen dengan segala konsekuensi atas tindakannya. Akibatnya mungkin agen membuat keputusan yang berlawanan dengan kepentingan principal. Moral hazard merupakan tindakan agen dalam memaksimasi utilitasnya dengan mengorbankan yang lain, dalam situasi dimana mereka tidak menanggung semua konsekuensi atau tidak menikmati secara penuh manfaat dari tindakan tersebut karena ketidakpastian, ketidaklengkapan atau keterbatasan kontrak. ${ }^{6}$

Bank Indonesia mendefinisikan risiko sebagai "potensi terjadinya kerugian akibat dari peristiwa tertentu". Sementara itu, risiko kerugian adalah sesuatu hal yang merupakan konsekuensi baik secara langsung atau tidak langsung dari suatu kejadian. Risiko ini bersifat tidak pasti, dimana ketika terjadi suatu keadaan yang tidak diinginkan dan dapat menimbulkan ketidaksesuaian dari hasil yang diharapkan.

Risiko dalam pembiayaan mudārabah menurut Karim adalah industry risk yang disebabkan oleh karakteristik dan kinerja keuangan masing-masing usaha yang bersangkutan, kondisi internal perusahaan nasabah, seperti manajemen, organisasi, pemasaran, teknis produksi, dan keuangan. Atau faktor negatif lainnya yang mempengaruhi perusahaan nasabah, seperti keadaan force majoure, permasalahan hukum, dan riwayat pembayaran nasabah pada bank lain.

Karim juga menjelaskan risiko muḍārabah dapat disebabkan business risk, yakni risiko yang dipengaruhi oleh industry risk yaitu risiko yang terjadi pada jenis usaha yang ditentukan dan dapat dipengaruhi oleh faktor negatif lainnya yang dapat mempengaruhi perusahaan nasabah. Risiko bisnis merupakan risiko yang melekat pada sebuah bisnis, misalnya omzet menurun dikarenakan harga barang meningkat ${ }^{7}$.

Selain itu, dalam pembiayaan muḍārabah memiliki risiko yang melekat dalam akadnya yaitu character risk. Character risk ini terjadi karena kelalaian nasabah, pelanggaran peraturan yang telah disepakati, pengelolaan internal perusahaan yang tidak

6 Padilla, Alexandre, Property Economics of Agency Problems (t.p: Working Pape, 2002), 6.

7 Karim, Adiwarman, Bank Islam: Analisis fiqih dan Keuangan (Jakarta: PT. Raja Grafindo Persada, 2010), 260-275. 
dilakukan secara profesional sesuai standar pengelolaan yang disepakati antara bank dan nasabah sehingga menimbulkan kerugian.

Unsur pokok dari manajemen risiko meliputi identifikasi, mengukur, memonitor, dan mengelola berbagai eksprosur risiko, akan tetapi semua itu tidak akan dapat diimplementasikan tanpa disertai dengan proses dan sistem yang jelas. Keseluruhan proses manajemen risiko ini harus meliputi seluruh departemen atau divisi kerja dalam lembaga sehingga tercipta budaya manajemen risiko. Dengan demikian manajemen risiko berfungsi sebagai pemberi peringatan dini terhadap kegiatan usaha bank atas risiko yang mungkin terjadi.

Dalam kerjasama mudārabah, diberikan peluang bagi para pebisnis yang tidak mempunyai modal, sehingga dengan sistem ini sedikit banyaknya akan memberdayakan potensi masyarakat untuk melakukan kegiatan ekonomi atas dasar kemitraan antara dirinya dan pemberi modal dalam menghasilkan keuntungan untuk dibagihasilkan sesuai dengan rasio yang telah disepakati. Namun pembiayaan mudāarabah mempunyai risiko yang tinggi karena akan selalu menghadapi adanya asimetri informasi dan moral hazard, maka șāhibul māl dapat menerapkan sejumlah batasan-batasan tertentu ketika menyalurkan pembiayaan kepada muḍārib. Batasan-batasan itu dikenal dengan incentive-compatible constraints dan melalui incentive-compatible constraints ini, mud̄ārib secara sistematis "dipaksa" untuk berperilaku memaksimalkan keuntungan bagi kedua belah pihak, baik bagi mudārib itu maupun bagi șāhibul māl.

Pada dasarnya, ada tiga panduan bagi incentive-compatible constraints, yaitu :

1. Menetapkan kovenan (syarat) agar porsi modal dari pihak mudāribnya lebih besar dan/atau mengenakan jaminan (higher stake in net worth/or collateral). Dalam praktiknya bisa diterapkan melalui penetapan nilai rasio hutang terhadap modal, penetapan agunan berupa fixed asset, penggunaan pihak penjamin.

2. Menetapkan kovenan agar mudārib melakukan bisnis yang risiko operasinya lebih rendah (lower operating risk). Dalam prakteknya, kovenan yang dapat diterapkan yaitu penerapan rasio maksimal fixed asset terhadap total aset, penerapan rasio maksimal dan biaya operasionalterhadap pendapatan operasi.

3. Menetapkan kovenan agar mudārib melakukan bisnis dengan arus kas yang transparan (lower fraction of unobservable cash flow). Dalam praktiknya dilakukan 
dengan monitoring secara acak, monitoring secara periodik, dan mengharuskan laporan keuangan diaudit. ${ }^{8}$

Risiko yang ditemukan dalam pembiayaan muḍ̄arabah adalah risiko keuangan, risiko investasi, risiko kepatuhan, risiko hukum, dan risiko fidusia. Dalam pembiayaan mudạarabah dimungkinkan menghadapi risiko kegagalan bayar dari mudārib. Kegagalan tersebut dapat dikarenakan mudārib mengalami kerugian dalam usahanya, mudārib mengalami kerugian akibat wanprestasi yang disengaja, atau keadaan force majour.

Risiko keuangan diakibatkan mudārib tidak dapat memenuhi kewajibannya kepada șāhibul māl. Kegagalan tersebut dapat dikarenakan adanya bencana atau force majoure, dapat juga dikarenakan adanya salah kelola dana yang dilakukan mudārib. Kesalahan tersebut bisa dikarenakan adanya ketidakjujuran dari muḍārib dalam hal pengelolaan dana. Hal tersebut dapat dimitigasi dengan melakukan analisa kelayakan mudāarib dengan prinsip 5C (Character, Capacity, Capital, Collateral, Condition), 1) Character artinya sifat atau karakter dari mudārib. Ciri khas dari pembiayaan mudāarabah adalah tuntutan rasa saling percaya yang tinggi antara nasabah dengan bank. Financing Team Leader dapat memperoleh informasi tentang karakter/watak calon nasabah dari pihak yang berhubungan dengan calon nasabah, misalnya rekan kerja. Bank Indonesia dan bank lain yang pernah menjadi kreditur bagi calon nasabah. Pihak bank juga melakukan cross check atas informasi yang diterima dari nasabah sendiri dengan informasi dari luar agar diperoleh penilaian yang objektif tentang calon nasabah. 2) Capacity artinya kemampuan mudārib untuk menjalankan usaha mengembalikan pembiayaan mudāarabah beserta membayar bagi hasil. 3) Capital artinya berapa besaran modal yang diperlukan pembiayaan. Bank dapat menentukan berapa dana yang akan disalurkan bagi nasabah dengan mengetahui posisi dan struktur keuangan nasabah. Besar kemampuan modal calon nasabah dapat diketahui dari laporan keuangan yang dimiliki perusahaan. 4) Collateral artinya jaminan yang dimiliki yang diberikan mudārib kepada bank. Ketentuan atas jaminan yang diajukan, yaitu nilai jaminan harus dapat menutupi kerugian yang dialami akibat kelalaian nasabah, jenis jaminan (barang bergerak atau tidak bergerak), status kepemilikan jaminan, dan kondisi jaminan (lokasi, keadaan, dan sebagainya). Jaminan yang diajukan dapat berupa tanah, gedung, benda

8 Karim, Adiwarman, Bank ..., 213-218. 
bergerak seperti kendaraan, atau potong gaji dari karyawan. 5).Condition artinya keadaan usaha atau prospek usaha ke depannya. Bank wajib menilai, memantau, dan mengambil langkah-langkah antisipasi agar kemungkinan dari gagal bayarnya muḍārib dapat diminimalisir. Hal ini dilakukan dengan analisa kelayakan dan dianggap layak, setiap bulannya bank harus melakukan pemantauan usaha muḍārib melalui laporan usaha yang wajib disetor ke Bank ${ }^{9}$

Dalam pembiayaan muḍārabah juga menghadapi risiko investasi. Risiko investasi muncul karena bank syariah memiliki pembiayaan berbasis bagi hasil, yang tidak dimiliki oleh bank konvensional. Risiko investasi yang dihadapi yaitu risiko ketidakjujuran mudāarib dalam melaporkan hasil usahanya.

Dengan melakukan uji kelayakan sangat penting karena untuk memenuhi tanggung jawab bank sebagai wakil dalam memegang amanah dari investor pemegang dana investasi pihak ketiga (DPK) yang berbasis bagi hasil (mudāarabah). Uji kelayakan dilakukan dengan mempertimbangkan keputusan yang dilihat dari catatan laporan keuangan mudārib, catatan masa lalu dari manajemen (laporan tahunan atau laporan triwulanan), dan rencana bisnisnya, dan juga aspek sumber daya manusia atau karyawannya. Kemudian bank perlu memastikan bahwa calon mudārib dapat menyusun laporan keuangan.

Risiko kepatuhan merupakan risiko akibat tidak dipatuhinya peraturanperaturan yang sudah dibuat baik peraturan internal maupun peraturan eksternal. "Risiko kepatuhan yang terjadi apabila dana yang diajukan tidak sesuai dengan realisasi, misalnya ketika pengajuan dana muḍārib bilang bahwa menggunakan dana untuk membiayai anggota dengan akad murābahah, tetapi pada kenyataannya dana tersebut digunakan oleh salah satu pengurus untuk membayar hutang-hutangnya"

Risiko Hukum merupakan risiko yang disebabkan adanya kelemahan aspek yuridis, misalnya adanya tuntutan hukum, ketiadaan peraturan perundang undangan yang mendukung atau pengikatan agunan yang tidak sempurna. Agunan yang dijaminkan oleh mudậrib harus benar-benar milik mudārib, berwujud, dan bernilai cukup. Karena jaminan rawan terhadap risiko hukum, maka pemeriksaan keabsahan jaminan berupa dokumen atau pemeriksaan fisik harus dilakukan. Pengikatan jaminan harus dilakukan dengan sempurna. Risiko hukum juga dapat terjadi apabila,

9 Khoiriyah Trianti, Manajemen Resiko Pembiayaan Mudārabah (t.tp: t.t, 2014), 11-12. 
penandatanganan kontrak dihadiri oleh orang yang tidak lengkap atau bukan yang seharusnya.

Risiko ini terjadi apabila mudāarib tidak memenuhi syarat-syarat dari kontrak yang disepakati, misalnya mudārib melakukan pemalsuan dokumen atau pemalsuan legalitas usaha. Jaminan yang diajukan kepada bank juga dalam permasalahan sengketa. Hal ini dimitigasi dengan melakukan ketelitian terhadap aspek legalitas jaminan, serta legalitas dan kelengkapan dokumen-dokumen yang dipersyaratkan. Untuk mengatasi risiko hukum, pihak bank melakukan pengecekan dengan teliti terkait legalitas usaha mudāarib, misalnya akta pendirian usaha, Surat Ijin Usaha Dagang (SIUP), Tanda Daftar Perusahaan, dan perijinan-perijinan yang lainnya.

Risiko fidusia timbul saat bank syariah gagal memenuhi perjanjian yang telah disepakati sebelumnya. Risiko fidusia terkait dengan fungsi bank syariah sebagai intermediator yang salah satu perannya adalah menyalurkan dana berbasis bagi hasil, seperti mudāarabah. Dalam pembiayaan mudārabah juga dapat menghadapi risiko salah dalam menilai kemampuan debitur dalam menilai usaha yang dibiayai dengan akad mudāarabah. Misalnya, seorang karyawan bank kurang berhati-hati dalam menilai kemampuan dari calon mudāarib. Hal ini bisa terjadi, karena karyawan tersebut terlalu percaya dengan informasi yang diberikan oleh mudāarib. Apabila hal ini terjadi, juga akan menimbulkan kerugian bagi pihak bank. Apabila ternyata muḍārib tersebut salah dalam mengelola dana yang diberikan, maka bank juga ikut menanggung kerugian dari akibat bank salah dalam menyalurkan dana ke muḍārib. Karena bank juga bertanggung jawab kepada para penabung dan deposan yang menghimpun dananya di Bank. Risiko ini nanti akan terlihat pada laba yang diberikan mudārib kepada bank. Apabila laba tidak sesuai dengan ekspetasi yang diharapkan oleh pihak bank. Maka bagi hasil kepada deposan juga akan berkurang. Laba berkurang ini dapat dikarenakan muḍārib tidak mampu dalam mengelola usahanya.

Mekanisme perhitungan bagi hasil yang diterapkan di dalam perbankan syariah terdiri dari dua sistem, yaitu:
a. Profit Sharing
b. Revenue Sharing ${ }^{10}$

10 Sofyan Rizal, Kontrak ..., 6-8. 
Profit sharing menurut etimologi adalah bagi keuntungan. Dalam kamus ekonomi diartikan pembagian laba. Profit secara istilah adalah perbedaan yang timbul ketika total pendapatan (total revenue) suatu perusahaan lebih besar dari biaya total (total cost).

Istilah lain profit sharing adalah perhitungan bagi hasil didasarkan kepada hasil bersih dari total pendapatan setelah dikurangi dengan biaya-biaya yang dikeluarkan untuk memperoleh pendapatan tersebut. Pada perbankan syariah istilah yang sering dipakai adalah profit and loss sharing, di mana hal ini dapat diartikan sebagai pembagian antara untung dan rugi dari pendapatan yang diterima atas hasil usaha yang telah dilakukan.

Sistem profit and loss sharing dalam pelaksanaannya merupakan bentuk dari perjanjian kerjasama antara pemodal (investor) dan pengelola modal (enterpreneur) dalam menjalankan kegiatan usaha ekonomi, dimana di antara keduanya akan terikat kontrak bahwa di dalam usaha tersebut jika mendapat keuntungan akan dibagi kedua pihak sesuai nisbah kesepakatan di awal perjanjian, dan begitu pula bila usaha mengalami kerugian akan ditanggung bersama sesuai porsi masing-masing. Kerugian bagi pemodal tidak mendapatkan kembali modal investasinya secara utuh ataupun keseluruhan, dan bagi pengelola modal tidak mendapatkan upah/hasil dari jerih payahnya atas kerja yang telah dilakukannya.

Keuntungan yang didapat dari hasil usaha tersebut akan dilakukan pembagian setelah dilakukan perhitungan terlebih dahulu atas biaya-biaya yang telah dikeluarkan selama proses usaha. Keuntungan usaha dalam dunia bisnis bisa negatif, artinya usaha merugi, positif berarti ada angka lebih sisa dari pendapatan dikurangi biaya-biaya, dan nol artinya antara pendapatan dan biaya menjadi balance. Keuntungan yang dibagikan adalah keuntungan bersih (net profit) yang merupakan lebihan dari selisih atas pengurangan total cost terhadap total revenue.

Revenue Sharing berasal dari bahasa Inggris yang terdiri dari dua kata yaitu, revenue yang berarti; hasil, penghasilan, pendapatan. Sharing adalah bentuk kata kerja dari share yang berarti bagi atau bagian. Revenue sharing berarti pembagian hasil, penghasilan, atau pendapatan. Revenue (pendapatan) dalam kamus ekonomi adalah hasil uang yang diterima oleh suatu perusahaan dari penjualan barang-barang (goods) dan jasa-jasa (services) yang dihasilkannya dari pendapatan penjualan (sales revenue). 
Dalam arti lain revenue merupakan besaran yang mengacu pada perkalian antara jumlah out put yang dihasilkan dari kegiatan produksi dikalikan dengan harga barang atau jasa dari suatu produksi tersebut.

Di dalam revenue terdapat unsur-unsur yang terdiri dari total biaya (total cost) dan laba (profit). Laba bersih (net profit) merupakan laba kotor (gross profit) dikurangi biaya distribusi penjualan, administrasi dan keuangan. Berdasarkan definisi di atas dapat di ambil kesimpulan bahwa arti revenue pada prinsip ekonomi dapat diartikan sebagai total penerimaan dari hasil usaha dalam kegiatan produksi, yang merupakan jumlah dari total pengeluaran atas barang ataupun jasa dikalikan dengan harga barang tersebut. Unsur yang terdapat di dalam revenue meliputi total harga pokok penjualan ditambah dengan total selisih dari hasil pendapatan penjualan tersebut. Tentunya di dalamnya meliputi modal (capital) ditambah dengan keuntungannya (profit).

Berbeda dengan revenue di dalam arti perbankan. Revenue bagi bank adalah jumlah dari penghasilan bunga bank yang diterima dari penyaluran dananya atau jasa atas pinjaman maupun titipan yang diberikan oleh bank. Revenue pada perbankan Syariah adalah hasil yang diterima oleh bank dari penyaluran dana (investasi) ke dalam bentuk aktiva produktif, yaitu penempatan dana bank pada pihak lain. Hal ini merupakan selisih atau angka lebih dari aktiva produktif dengan hasil penerimaan bank.

Perbankan Syariah memperkenalkan sistem pada masyarakat dengan istilah Revenue Sharing, yaitu sistem bagi hasil yang dihitung dari total pendapatan pengelolaan dana tanpa dikurangi dengan biaya pengelolaan dana. Lebih jelasnya Revenue sharing dalam arti perbankan adalah perhitungan bagi hasil didasarkan kepada total seluruh pendapatan yang diterima sebelum dikurangi dengan biaya-biaya yang telah dikeluarkan untuk memperoleh pendapatan tersebut. Sistem revenue sharing berlaku pada pendapatan bank yang akan dibagikan dihitung berdasarkan pendapatan kotor (gross sales), yang digunakan dalam menghitung bagi hasil untuk produk pendanaan bank.

Beberapa permasalahan yang dihadapi sehingga mudāarabah menjadi kurang berkembang, diidentifikasikan antara lain sebagai berikut :

Pertama, kontrak profit loss sharing dikaitkan dengan agency problem manakala seorang pengusaha tidak mempunyai insentif untuk memberikan usaha tetapi mempunyai insentif untuk melaporkan profit yang lebih rendah dibandingkan dengan 
pembiayaan pribadi dari manager. Argumen ini berdasarkan ide bahwa pihak-pihak pada transaksi bisnis akan melalaikan jika mereka dikompensasi kurang dari kontribusi marginal pada proses produksi, dan manakala ini terjadi pada kasus profit loss sharing, kaum kapitalis ragu-ragu untuk berinvestasi berdasarkan basis profit loss sharing.

Kedua, kontrak profit loss sharing membutuhkan jaminan agar dapat berfungsi secara efisien. Sedikitnya jaminan hak properti pada kontrak profit loss sharing menyebabkan kegagalan adopsi karena tidak ada aturan yang melandasi. Pada praktiknya di Indonesia, jaminan hak properti atas profit-loss sharing belum diatur dengan tegas dan jelas

Ketiga, perbankan Islam menawarkan resiko yang lebih kecil dari pembiayaan dibandingkan dengan perbankan konvensional. Hal ini berdasarkan konsep mudāarabah dan mushārakah yang dianutnya. Tetapi seringkali pelaksanaannya manajemen aset dari mudāarabah dan mushārakah tidak sesuai ketentuan yang berlaku. Idealnya, dana pada perbankan syariah disalurkan melalui kegiatan investasi pada asset riil. Tetapi pada kenyataannya di Indonesia, pengelolaan aset pada perbankan syariah masih terpusat pada Sertifikat Wạ̣ $\vec{i}$ ah Bank Indonesia

Keempat, batasan peran investor pada manajemen dan dikotomi struktur keuangan dari kontrak profit loss sharing menimbulkan ketidak partisipasian. Mereka tidak berbagi kontrak berdasarkan partisipasi pengambilan keputusan. Disatu sisi terlihat hanya pihak manajemen yang mengelola dana sedangkan investor hanya menikmati hasilnya

Kelima, pembiayaan ekuitas tidak tepat bagi pembiayaan proyek jangka pendek manakala dihadapkan pada tingkat risiko yang tinggi (efek diversifikasi waktu pada ekuitas). Pada kasus di Indonesia, dimana banyak pengelolaan dana perbankan syariah yang disalurkan melalui sertifikat waḍ̄’ah bank Indonesia, menimbulkan risiko yang tinggi jika pembiayaan tersebut berjangka pendek dan lebih berisiko lagi jika bank syariah menyalurkan pengelolaan dana melalui Jakarta Islamic Index. ${ }^{11}$

Pengoperasian bank syariah ini tidak terlepas dengan tuntutan pelaksanaan tata kelola perusahaan yang baik (Good Corporate Governance (GCG)). Dengan melaksanakan konsep GCG, diharapkan tercipta citra lembaga yang dapat dipercaya.

11 Humayon A. Dar and John R. Presle, Lack of Profit Loss Sharing in Islamic Banking: Management and Control Imbalances (t.p: Loughborough University, 2001), 4-6. 
Artinya ada keyakinan bahwa bisnis perbankan dikelola dengan baik sehingga dapat tumbuh secara sehat, kuat, dan efisien.

Rancangan tentang mekanisme pengawasan korporasi yang efektif untuk membuat para manajer bertindak dalam kepentingan terbaik bagi para pemegang saham telah menjadi perhatian utama dalam wilayah dari tata kelola perusahaan dan keuangan . Corporate governance merupakan mekanisme pengendalian untuk mengatur dan mengelola perusahaan dengan maksud untuk meningkatkan kemakmuran dan akuntabilitas perusahaan, yang tujuan akhirnya untuk meningkatkan nilai pemegang saham

Penerapan prinsip-prinsip GCG menjadi suatu keharusan bagi sebuah institusi, termasuk di dalamnya institusi bank syariah. Hal ini lebih ditujukan kepada adanya tanggung jawab publik (public accountability) berkaitan dengan kegiatan operasional bank yang diharapkan benar-benar mematuhi ketentuan-ketentuan yang telah digariskan dalam hukum positif. Di samping itu juga berkaitan dengan kepatuhan bank syariah terhadap prinsip-prinsip syariah sebagaimana yang telah digariskan dalam al-Qur'an, Hadis, dan Ijmak para ulama.

Pengertian GCG sendiri menurut Pasal 1 angka 6 Peraturan Bank Indonesia No.8/4/ PBI/2006 tentang Pelaksanaan Good Corporate Governance Bagi Bank Umum. Disebutkan bahwa good corporate governance adalah tata kelola bank yang menerapkan prinsip-prinsip keterbukaan (transparancy), akuntabilitas (accountability), pertanggung jawaban (responsibility), independensi (independency), dan kewajaran (fairness). Secara umum, fungsi bank syariah sama dengan perbankan konvensional yakni sebagai lembaga intermediasi (intermediary institution) yang mengerahkan dana dari masyarakat dan menyalurkan kembali dana-dana tersebut kepada masyarakat yang membutuhkannya dalam bentuk fasilitas pembiayaan. Karena itu, prinsip-prinsip pokok GCG yang dikembangkan secara umum untuk sistem perbankan berlaku pula pada bank syariah. Kelima prinsip pokok GCG di atas dapat dijabarkan sebagai berikut: 1) Prinsip Keterbukaan (transparancy). Artinya, bank syariah berkewajiban memberi informasi tentang kondisi dan prospek perbankannya secara tepat waktu, memadai, jelas, dan akurat. Informasi itu juga harus mudah diakses oleh stakeholders sesuai dengan haknya. Hal ini dapat digunakan sebagai dasar bagi mereka untuk menilai reputasi dan tanggung jawab bank syariah; 2) Prinsip Akuntabilitas, di mana bank syariah harus menetapkan 
tanggung jawab yang jelas dari setiap komponen organisasi, selaras dengan visi, misi, sasaran usaha, dan strategi perusahaan. Setiap komponen organisasi mempunyai kompetensi sesuai dengan tanggung jawab masing-masing. Selain itu, bank harus memastikan ada dan tidaknya check and balance dalam pengelolaan bank. Bank harus memiliki ukuran kinerja dari semua jajarannya berdasarkan ukuran yang disepakati secara konsisten, sesuai dengan nilai perusahaaan (corporate values), sasaran usaha, strategi bank, serta memiliki reward and punishment system; 3) Prinsip Tanggung Jawab (responsibility). Artinya, bank syariah harus memegang prinsip prudential banking practices. Prinsip ini harus dijalankan sesuai dengan ketentuan yang berlaku, agar operasional perbankan syariah tetap berjalan sesuai dengan yang diharapkan. Bank pun harus mampu bertindak sebagai good corporate citizen (perusahaan yang baik); 4) Prinsip Independensi. Bank syariah harus mampu menghindari dominasi yang tidak wajar oleh stakeholders. Pengelola bank tidak boleh terpengaruh oleh kepentingan sepihak. Bank syariah harus menghindari segala bentuk benturan kepentingan (conflict of interest); 5) Prinsip Keadilan (fairness), artinya bank syariah harus memperhatikan kepentingan seluruh stakeholders berdasarkan azas kesetaraan dan kewajaran (equal treatment). Namun, bank juga perlu memberi kesempatan kepada stakeholders untuk memberi masukan dan saran demi kemajuan bank syariah. ${ }^{12}$

GCG pada lembaga keuangan, khususnya bank memiliki keunikan bila dibandingkan governance pada lembaga keuangan non-bank. Hal ini lebih disebabkan oleh kehadiran deposan sebagai suatu kelompok stakeholders yang kepentingannya harus diakomodir dan dijaga. Sementara itu khusus dalam perbankan syariah dikenal adanya prinsip-prinsip syariah yang mendukung bagi terlaksananya prinsip GCG dimaksud, yakni keharusan bagi subjek hukum termasuk bank untuk menerapkan prinsip kejujuran (șiddīq), edukasi kepada masyarakat (tablīgh), kepercayaan (amanah), dan pengelolaan secara profesional (fațānah).

\section{Kesimpulan}

Dari pembahasan diatas dapat disimpulkan hal-hal sebagai berikut :

12 Thomas S. Kaihatu, Good Corporate Governance dan Penerapannya di Indonesia, (t.p:ttp, 2006), 2 . 
1. Manajemen risiko dalam pembiayaan mudārabah di adalah suatu upaya untuk meminimalisir risiko yangterjadi, baik pada tahapan pra akad dan pasca akad. Mitigasi pra akad dilakukandengan mematuhi Standard Operational Procedure yang ditetapkan internal bank,melakukan seleksi calon mudārib, dan melakukan analisa kelayakan usaha calon mudāarib. Sedangkan mitigasi risiko pasca akad dilakukan dengan monitoring secara berkala kondisi usaha mudārib dan melakukan pembinaan usaha mudārib.

2. Sharing adalah sesuatu yang sangat dianjurkan dalam Islam agar kita dapat saling membantu dalam menanggung resiko usaha tentu yang sesuai dengan syariah

3. Pelaksanaan Good Corporate Governance Bagi Perbankan Syariah. Good corporate governance adalah tatakelola bank yang menerapkan prinsip - prinsip keterbukaan (transparancy), akuntabilitas (accountability), pertanggung jawaban (responsibility), independensi (independency), dan kewajaran (fairness).

\section{Daftar Pustaka}

Antonio, Muhammad Syafiei, Bank Syariah: Dari Teori ke Praktik (Jakarta: Gema Insani, 2001).

Dewan Standar Akuntansi Keuangan, 2007. PSAK No. 105 (Jakarta: Ikatan Akuntan Indonesia, 2007).

Dewan Syariah Nasional. Majelis Ulama Indonesia, Himpunan Fatwa Dewan Syariah Nasional (t.tp: CV Gaung Persada, 2006).

Karim, Adiwarman, Bank Islam: Analisis fiqih dan Keuangan (Jakarta: PT. Raja Grafindo Persada, 2010).

Humayon A. Dar and John R. Presley, Lack of Profit Loss Sharing in Islamic Banking: Management and Control Imbalances (Loughborough University, 2001).

Khoiriyah Trianti, Manajemen Resiko Pembiayaan Mudharabah (2014).

Mufraini, Arief, Modul Perbankan Syariah Landasan Teori dan Praktek (Jakarta: Fakultas Ekonomi dan Ilmu Sosial UIN Jakarta, 2008).

Thomas S. Kaihatu, "Good Corporate Governance dan Penerapannya di Indonesia, Jurnal Manajemen dan Kewirausahaan Vol 8 No 1 Maret 2006.

Mustafa Edwin Nasution dan Ranti Wiliasih, "Profit Sharing dan Moral Hazard dalam Penyaluran Dana Pihak Ketiga Bank Umum Syariah di Indonesia," Jurnal Ekonomi Pembangunan Indonesia, Vol.VIII No.02, Januari 2007. 
Sofyan Rizal, Kontrak Mudharabah Permasalahan dan Alternatif Solusi. 